\title{
MOVERS
}

\begin{abstract}
William Chameides, dean, Nicholas School of the Environment and Earth Sciences, Duke University, Durham, North Carolina
\end{abstract}

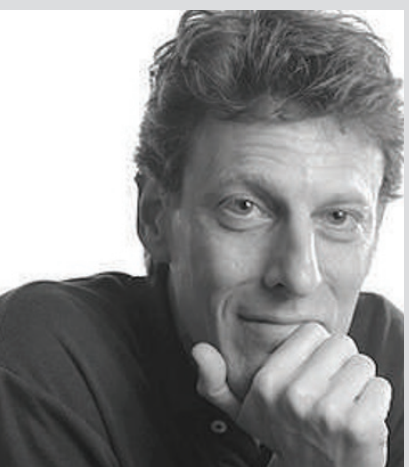

\begin{abstract}
2005-07: Chief scientist, Environmental Defense, Washington DC 2005-present: Regents' professor emeritus, School of Earth and Atmospheric Sciences, Georgia Institute of Technology, Atlanta, Georgia 1998-2005: Smithgall chair in atmospheric sciences, Georgia Institute of Technology, Atlanta, Georgia
\end{abstract}

When he went to college, Bill Chameides was intent on becoming a lawyer. But he exchanged his legal dreams for science - first physics then atmospheric sciences - and became one of the environment's star witnesses.

It was dumb luck, he says, that led him to first study ozone in the troposphere, which resulted in him developing a theory of tropospheric ozone production while completing his PhD at Yale University. From there he took a postdoc at the University of Michigan, Ann Arbor, working with the current US National Academy of Sciences president Ralph Cicerone, who had just published pioneering work on ozone-depleting chlorofluorocarbons. Chameides found watching Cicerone bridge the sciencepolicy divide inspiring. Although most scientists at the time focused on atmospheric gas chemistry, Chameides laid down the foundation for dynamic atmospheric chemistry between liquids and gases.

Chameides then spent 25 years at the Georgia Institute of Technology, eventually becoming chair of the atmospheric-sciences department where he pursued policy-relevant research. Two years ago, he made an unorthodox move to become chief scientist of Environmental Defense, an advocacy group based in New York City. "I felt I needed to do more to advance the cause of good environmental stewardship," he says.

Chameides thought he was burning his bridges to academia. But he continued to do research, and in doing so kept his career options open. During Chameides' time at Environmental Defense, the group helped to pass landmark laws and won two important Supreme Court decisions. But academia wouldn't let him go. Duke University sought him out to head the Nicholas School of the Environment and Earth Science - a programme noted for its ambitious goals of training students in the physical, biological, social and policy implications of environmental science.

Cicerone says creating a broad programme that merges research and liberal arts agendas is a challenge. But, he adds, Chameides has the qualifications to pull it off. Chameides is already planning to lead the Nicholas School faculty in an assessment of the major environmental and social problems facing the world over the next 25 years, and explore how Duke can best address them. His goal, he says, is to help shape the next generation of scientists, policymakers and environmental stewards.

Virginia Gewin
NETWORKS \& SUPPORT

\section{Keep your eye on the goal}

The experience of Daniel Rizzuto (see Nature 447, 350; 2007) shows how an adviser's support and a timely decision can lead to a gratifying new start. Rizzuto swapped from studying brain-machine interfaces to working for his former adviser as project my experience, such opportunities seldom arise, so determination and sharp job-hunting skills are priceless.

My journey began with a practical objective: to find a research position in the biotechnology industry. But I had no idea how tortuous the road would be. After my PhD studies at the Weizmann Institute of Science in Rehovot, Israel, in the field of drug targeting and delivery in 2000, I thought I'd benefit from a business degree, so I pursued an MBA at an Israeli university.

In my second year I was offered a postdoc at the MD Anderson Cancer Center in Houston, Texas, to study tumour angiogenesis and biomarkers. Although this did not quite fit my career plan, it held the promise of gaining new skills, experiences and contacts. With much enthusiasm, I interrupted my studies and spent the next three years doing lab research. Nevertheless, my end goal was to land a job in biotech, so I was pleased when my mentor established a startmanager on a big new contract. But in up based on the lab's research, encouraging trainees to maintain industry-standard lab notebooks, participate in intellectual-property sessions with patent attorneys, apply strict confidentiality policy, meet with investors and prepare presentations.

Then, with my visa about to expire, I thought I'd found what I was looking for on a second postdoc - my new adviser was an internationally recognized scientist with ties to many respected companies. Unfortunately, I soon discovered our outlooks didn't mesh and she didn't share my interest in commercializing science.

Still, I didn't despair. I completed an interview-skills workshop, upgraded my $C V$, methodically read career sections on the web, got in touch with my network of colleagues in industry and carefully targeted openings. I took a direct and sincere approach with people who might hire me, remaining flexible about job type and confident about my professional value.

Like Rizzuto's, my academic mentors had a role in creating opportunities and independence. The hardships I encountered have definitely helped me navigate the job market and prepare for the future. Limor Chen is a scientist at Teva Pharmaceutical Industries' R\&D Initiative in Jerusalem, Israel.

\section{POSTDOC JOURNAL}

\section{To teach or not to teach?}

One of the biggest surprises of my fledgling academic career is how much I've come to enjoy teaching. Helping students to understand a difficult concept, or seeing their imagination gripped by a new idea, is immensely rewarding. But right now, indulging this passion is not without its dangers. I had a chance to ponder the conflicting risks and rewards during two weeks that I spent out in the field with my Johannesburg students, looking at some of the oldest rocks on the planet.

I enjoyed myself, and because good knowledge of the material is necessary to teach other people properly, l learnt a lot myself about what ancient lavas and sediments - the subjects of our study - could tell us about Earth 3.5 billion years ago.

On the other hand, it could be argued that the short-term nature of my position here means I can ill afford to spend time away from my research. Involving myself in teaching is 'good experience' to put on my CV, but counts for nothing without more tangible qualifications such as a good publication record.

It seems like a bit of a paradox. But to give myself the best chance of getting a teaching position in the future, I may have to ration how much teaching

I actually do in the present.

Chris Rowan is a postdoctoral student in the geology department at the University of Johannesburg, South Africa. 